\title{
Kajian eksperimental mekanisme rol pemipih pada prototipe mesin pemipih emping beras
}

\author{
Suhendra ${ }^{1^{*}}$, Feby Nopriandy ${ }^{2}$, Irma Fahrizal B.N. ${ }^{3}$ \\ 1,2,3Jurusan Teknik Mesin, Politeknik Negeri Sambas \\ JI. Raya Sejangkung, Sambas, Kalimanatan Barat, Indonesia \\ ${ }^{*}$ Corresponding author: aka.suhendra@yahoo.com
}

\begin{abstract}
Rice quaker are traditional food from the Sambas regency. The manufacture of rice quaker has been traditionally done by pounding it. Economically, the production capacity of traditionally made rice quaker is so low that it needs to be increased by changing the manual to mechanical flattening system. The purpose of this research is designing a prototype machine for flattening rice quaker as well as conducting experimental studies on the flattening process. The research stages were to design, manufacture, and test the performance of the flattening rice quaker. The independent variables of the study were the gap width and the number of flattening, while the dependent variables of the study were thickness and percentage damage of rice quaker. The width of the gap was varied into $0.4 \mathrm{~mm}, 0.6 \mathrm{~mm}, 0.8 \mathrm{~mm}$, and $1.0 \mathrm{~mm}$, while the number of flattening was varied to 1,2, and 3 times the flattening. The result of the construction of the prototype rice quaker machine is in accordance with the initial design, and can work to flatten rice quaker. The engine test was carried out at a flat roller speed of 360 rpm. The thickness of the rice quaker made traditionally, $0.98 \mathrm{~mm}$, can be approached by flattening using a machine at a gap width of $0.8 \mathrm{~mm}$ with 2 flakes resulting in a thickness of $0.96 \mathrm{~mm}$ quaker with a percentage of damage of $38.52 \%$. In general, the level of damage to the resulting rice quaker is still very high, so further analysis is needed.
\end{abstract}

Keywords: Rice quaker, gap width, flattening machine, flat rollers.

\begin{abstract}
Abstrak
Emping beras merupakan jenis makanan tradisional khas daerah Kabupaten Sambas. Pembuatan emping beras selama ini dilakukan secara tradisional dengan cara ditumbuk. Secara ekonomi, kapasitas produksi emping beras yang dibuat secara tradisional sangat rendah sehingga perlu ditingkatkan dengan mengubah sistem pemipihan manual menjadi mekanis. Upaya tersebut dilakukan melalui penelitian yang bertujuan merancang bangun prototipe mesin pemipih emping beras serta melakukan kajian eksperimental terhadap proses pemipihan emping beras. Tahapan penelitian adalah merancang, membuat, dan melakukan uji kinerja mesin pemipih emping beras. Variabel bebas penelitian adalah lebar celah dan jumlah pemipihan, sedangkan variabel tak bebas penelitian adalah ketebalan dan persentase kerusakan emping beras. Lebar celah divariasikan menjadi $0,4 \mathrm{~mm}, 0,6 \mathrm{~mm}, 0,8 \mathrm{~mm}$ dan $1,0 \mathrm{~mm}$ sedangkan jumlah pemipihan divariasikan menjadi 1, 2, dan 3 kali pemipihan. Hasil konstruksi prototipe mesin pemipih emping beras sesuai dengan rancangan awal, dan dapat bekerja memipih emping beras. Pengujian mesin dilakukan pada kecepatan rol pemipih $360 \mathrm{rpm}$. Ketebalan emping beras yang dibuat secara tradisional yaitu $0,98 \mathrm{~mm}$ dapat didekati dengan pemipihan menggunakan mesin pada lebar celah $0,8 \mathrm{~mm}$ dengan 2 kali pemipihan menghasilkan tebal emping 0,96 mm dengan persentase kerusakan 38,52\%. Secara umum tingkat kerusakan emping beras yang dihasilkan masih sangat tinggi, sehingga perlu dilakukan analisis lebih lanjut.
\end{abstract}

Kata kunci : Emping beras, lebar celah, mesin pemipih, rol pemipih. 


\section{Pendahuluan}

Emping beras atau dalam Bahasa Sambas disebut amping merupakan emping yang terbuat dari padi muda. Kegiatan membuat emping beras (mengamping) di Kabupaten Sambas merupakan tradisi yang telah dilakukan secara turun temurun oleh petani. Membuat emping beras dilakukan sebelum panen padi dilakukan, sebagai perwujudan rasa syukur terhadap hasil panen yang telah diberikan. Kegiatan ini juga dimanfaatkan sebagai ajang silaturahmi para petani di sebuah desa, karena membuat emping beras biasanya dipusatkan di suatu lokasi sebagai tempat berkumpulnya seluruh warga desa. Setelah panen selesai, emping beras sudah sulit diperoleh karena bahan untuk membuat emping beras tidak tersedia.

Tahapan membuat emping beras dimulai dengan memilih padi di sawah, melepaskan bulir padi dari tangkainya, menyangrai, menumbuk dan membersihkan emping beras. Padi yang digunakan dalam pembuatan emping beras dipilih dari padi yang hampir matang. Tingkat kematangan padi yang dipilih sangat menentukan rasa dan kualitas emping beras yang dihasilkan.

Proses pelepasan bulir dari tangkai padi dilakukan secara manual menggunakan kayu. Teknik ini digunakan untuk meminimalisasi kerusakan bulir padi yang dilepas dari tangkainya. Menyangrai bulir padi dilakukan dalam wajan dengan cara diaduk secara terus-menerus. Tingkat kematangan ditandai dengan timbulnya bunyi letupan pada bulir padi yang disangrai. Bulir padi yang telah disangrai selanjutnya didinginkan lalu ditumbuk secara tradisional menggunakan alu dan lessung.

Proses penumbukan bertujuan untuk memipihkan bulir padi dan melepaskan kulit dari bulir tersebut. Kegiatan ini umumnya dilakukan oleh 2 - 3 orang dalam 1 lessung, proses penumbukan dikerjakan secara bergantian, dan memerlukan waktu pengerjaan sekitar 1,5 menit untuk 1 kali proses pengerjaan. Volume bahan yang digunakan untuk 1 kali proses pengerjaan sekitar $150 \mathrm{ml}$ padi muda yang telah disangrai. Kapasitas penumbukan secara manual dapat menghasilkan emping beras sekitar 6 liter/jam.

Permasalahan proses produksi emping beras yang dilakukan secara tradisional adalah rendahnya kapasitas produksi yang dihasilkan. Tahapan penting dalam pembuatan emping beras yang perlu dilakukan inovasi adalah proses pemipihan emping. Kapasitas pemipihan emping beras dapat ditingkatkan dengan mengubah sistem pemipihan manual menjadi mekanis.

Penelitian secara spesifik yang membahas tentang sistem pemipihan pada emping beras masih belum dilakukan. Analisis pendekatan dapat dilakukan pada beberapa penelitian tentang mekanisme sistem pemipih pada jagung atau melinjo. Rancang bangun mesin pemipih emping jagung menggunakan mekanisme sepasang rol yang saling berlawanan arah telah dilakukan [1]. Hasil pengujian menghasilkan kapasitas pemipihan 1,57 $\mathrm{kg} / \mathrm{jam}$ untuk jagung yang direbus 2 jam dan mendapatkan kapasitas $1,33 \mathrm{~kg} / \mathrm{jam}$ untuk jagung yang direbus 2 jam dilanjutkan penjemuran 6 jam. Penelitian lainnya yaitu pembuatan mesin emping melinjo menggunakan sistem transmisi puli dengan 3 pasang rol sebagai mekanisme pemipih menghasilkan kapasitas $15 \mathrm{~kg} / \mathrm{jam}$ [2]. Mesin pemipih emping melinjo menggunakan mekanisme pemipih berupa silinder berkapasitas $50 \mathrm{~kg} / \mathrm{jam}$ yang dioperasikan pada putaran $286 \mathrm{rpm}$ [3]. Alat pemipih semi mekanis biji melinjo yang mampu memproduksi emping melinjo 15,292 gram dengan waktu 54 detik [4].

$$
\text { Mekanisme tumbukan dalam }
$$
pembuatan emping beras seraca manual dapat didekati dengan konsep pemipihan mekanis menggunakan rol. Teknik pemipihan secara mekanis memungkinkan kapasitas pemipihan yang lebih tinggi dibanding pemipihan secara manual. Oleh karena itu, perlu dirancang bangun mesin pembuat emping beras menggunakan rol sebagai mekanisme pemipih. Beras yang dibuat emping dilewatkan pada celah antara rol yang berputar berlawanan arah. 
Penelitian dilakukan bertujuan untuk merancang bangun prototipe mesin pemipih emping beras menggunakan mekanisme rol pemipih serta melakukan kajian eksperimental terhadap ukuran lebar celah rol pemipih dan jumlah pemipihan untuk mendapatkan kualitas emping beras yang baik.

\section{Tinjauan Pustaka}

\section{Potensi emping beras}

Emping beras dihasilkan dari padi yang belum matang, dibuat dengan cara di sangrai dan ditumbuk. Emping beras termasuk jenis serealia dan secara fisik, emping beras menyerupai sereal oat. Jenis sereal umumnya banyak dimanfaatkan sebagai pengganti pangan untuk sarapan di pagi hari. Jenis tanaman serealia yang banyak dibudidayakan adalah gandum, padi, barli, oats, jagung, dan shorgum [5]. Jenis makanan serealia memiliki kandungan karbohidrat yang tinggi sehingga dapat dijadikan sebagai makanan pokok manusia, hewan dan dimanfaatkan pada industri pangan.

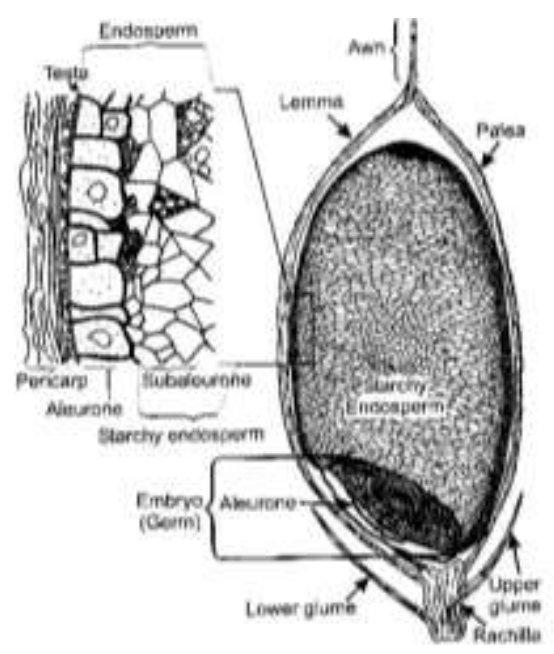

Gambar 1. Struktur biji padi [6]

Struktur biji sereal terdiri dari sekam sebagai kulit, dedak sebagai pelindung endosperma dan benih, benih sebagai embrio, dan endosperma merukan bagian penting untuk makanan [5]. Sebutir gabah memiliki bobot antara 12-44 mg pada kadar air 0\% sedangkan bobot sekam sekitar $20 \%$ bobot gabah [7].
Gabah yang belum matang merupakan bahan baku pembuatan emping beras. Jenis makanan ini merupakan salah satu kuliner tradisional di Kabupaten Sambas yang memiliki cita rasa unik. Secara finansial, sebetulnya emping beras memiliki potensi yang sangat tinggi karena harga jual emping beras jauh lebih tinggi dibanding harga jual beras. Dukungan sumber daya alam dan banyaknya ketersediaan lahan sawah dapat menambah potensi pengembangan emping beras sebagai produk unggulan daerah.

Potensi yang dimiliki Kabupaten Sambas untuk pengembangan agribisnis emping beras sangat besar. Hal ini didukung oleh luasnya areal tanam untuk padi sawah. Luas lahan sawah di Kabupaten Sambas mencapai 68.644 hektar, dengan hasil panen padi tahun 2017 mencapai 169.465 ton [8].

\section{Mekanisme pemipihan}

Mekanisme yang digunakan dalam proses pemipihan emping umumnya menggunakan metode tumbuk atau tekan. Beberapa penelitian pendukung dapat dijadikan rujukan dalam merancang bangun mesin pemipih emping menggunakan mekanisme rol pemipih [9].

Mesin pemipih jagung dengan mekanisme sepasang rol pemipih dioperasikan pada kecepatan rol 7,15 rpm, sistem transmisi menggunakan puli dan sabuk-v tipe B [1]. Mesin pemipih ini digerakkan oleh motor listrik berdaya 0,5 HP dan dapat digunakan untuk memipihkan jagung dengan ketebalan $1,5-2 \mathrm{~mm}$. Penelitian yang dilakukan masih belum membahas kualitas emping yang dihasilkan dan kapasitas pemipihan masih relatif rendah sehingga masih perlu ditingkatkan.

Mesin pemipih emping melinjo menggunakan 3 pasang rol pemipih, pasangan pertama berjarak $5 \mathrm{~mm}$ (edge to edge), dua pasang berikutnya berjarak 0,5 $\mathrm{mm}$ dan $0,4 \mathrm{~mm}$ [2]. Hasil pengujian menghasilkan emping melinjo berukuran relatif seragam $(4-5 \mathrm{~mm})$.

Perancangan mesin emping jagung dengan rol pengatur telah dilakukan [10]. Hasil rancangan bertujuan agar mesin 
bekerja secara kontinyu untuk memudahkan proses pemipihan biji jagung. Kapasitas rancangan mesin emping jagung ini adalah $121 \mathrm{~kg} / \mathrm{jam}$ yang dapat meningkatkan waktu proses produksi hingga 35 menit dari mesin sebelumnya. Hasil penelitian yang dilakukan baru sebatas perancangan, sehingga perlu dilakukan rekayasa dan uji kinerja terlebih dahulu untuk mendapatkan kapasitas dan nilai kinerja ril mesin pembuat emping.

Berdasarkan sifat fisik padi, metode pemipihan emping beras sangat memungkinkan menggunakan rol pemipih. Beberapa penelitian tentang mekanisme pemipihan menggunakan rol dalam pembuatan emping juga telah dilakukan. Faktor yang perlu diperhatikan dalam pembuatan mesin pemipih adalah lebar celah dan putaran rol pemipih.

\section{Metode Penelitian}

Tahap pelaksanaan penelitian dapat dilihat pada diagram alir penelitian berikut.

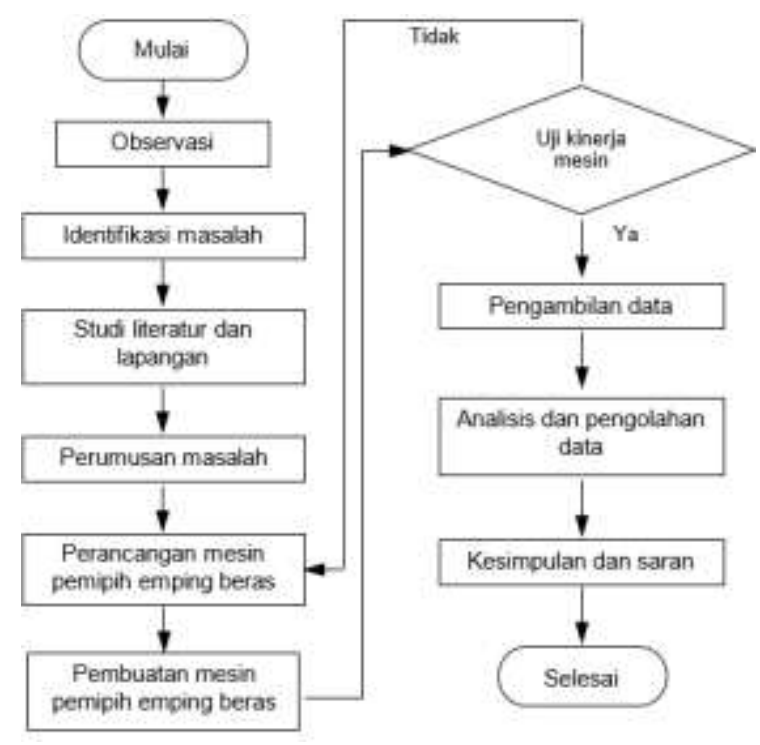

Gambar 2. Diagram alir penelitian

Mesin pemipih emping beras didesain menggunakan sepasang rol. Rol pemipih dibuat dari bahan kayu keras berbentuk silinder. Sumber penggerak mesin pemipih menggunakan motor listrik menggunakan sistem transmisi puli dan sabuk-v.

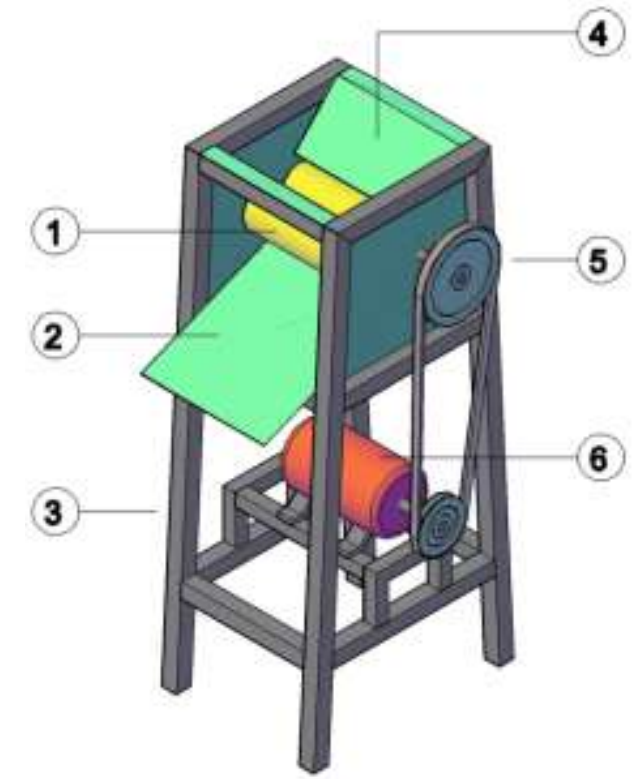

Gambar 3. Desain mesin pemipih emping beras

Keterangan Gambar:

1. Rol pemipih

2. Saluran keluar bahan

3. Rangka

4. Hopper

5. Sistem transmisi

6. Motor listrik

Proses pembuatan mesin pemipih emping beras meliputi kegiatan pembubutan, pengeboran, pengelasan dan pembentukan plat. Langkah-langkah dalam pembuatan mesin emping beras adalah pembuatan rangka, pemasangan rol pemipih, pembuatan saluran masuk dan saluran keluar emping, pemasangan motor penggerak dan pemasangan tutup bodi mesin pemipih.

Alat-alat dan bahan uji yang digunakan dalam penelitian ini adalah prototipe mesin pemipih emping beras, beras ketan, wajan, timbangan, kompor gas, jangka sorong, wadah, tachometer dan feeler gauge.

Prosedur pengujian dilakukan terlebih dahulu dengan mendesain dan membuat mesin pemipih emping beras, selanjutnya menentukan variabel yang digunakan dalam penelitian. Variabel bebas (independent variable) penelitian adalah lebar celah pemipihan dan jumlah pemipihan. Lebar celah divariasikan menjadi 4 perlakuan yaitu 
$0.4 \mathrm{~mm}, 0.6 \mathrm{~mm}, 0.8 \mathrm{~mm}$ dan $1.0 \mathrm{~mm}$. Pengukuran lebar celah dilakukan menggunakan feeler gauge. Jumlah pengerolan divariasikan menjadi 3 perlakuan yaitu 1, 2 dan 3 kali pemipihan. Variabel tak bebas (dependent variable) penelitian adalah tebal emping beras yang dihasilkan dan persentase emping rusak.

Tebal emping beras yang dihasilkan diukur menggunakan jangka sorong, sedangkan persentase emping rusak dihitung menggunakan persamaan 1 [11].

$\mathrm{PER}=\frac{E R}{E R+E B} \times 100 \%$

Keterangan :

PER = Persentase emping rusak (\%)

ER = Emping rusak (butir)

$\mathrm{EB}=$ Emping baik (butir)

Tahapan awal pengujian dilakukan dengan mempersiapkan sampel uji (beras ketan) sebanyak 50 gr untuk setiap pengujian. Sampel uji selanjutnya dipanaskan dalam wajan sekitar 2-3 menit menggunakan api kecil. Lakukan pengadukan secara terus menerus hingga terdengar bunyi letupan beberapa kali. Masukkan sampel uji dalam kondisi panas pada mesin pemipih emping beras. Lakukan pengambilan data hasil pengujian terhadap emping beras hasil pemipihan mesin.

Data yang diambil dalam penelitian ini meliputi data tebal emping beras yang dihasilkan dan persentase emping rusak. Data tersebut selanjutnya dianalisis untuk mengetahui pengaruh perubahan lebar celah dan jumlah pemipihan terhadap kualitas emping yang dihasilkan. Hasil analisis digunakan untuk menentukan hubungan antar variabel, menemukan kekurangan dan kelemahan mesin hasil rancangan serta menarik kesimpulan akhir terhadap penelitian yang dilakukan

\section{Hasil dan Pembahasan}

\section{Hasil rancang bangun mesin}

Prototipe mesin pemipih emping beras hasil rancang bangun dapat dilihat pada
Gambar 4. Spesifikasi hasil rancang bangun prototipe mesin pemipih emping beras dapat dilihat pada Tabel 1.

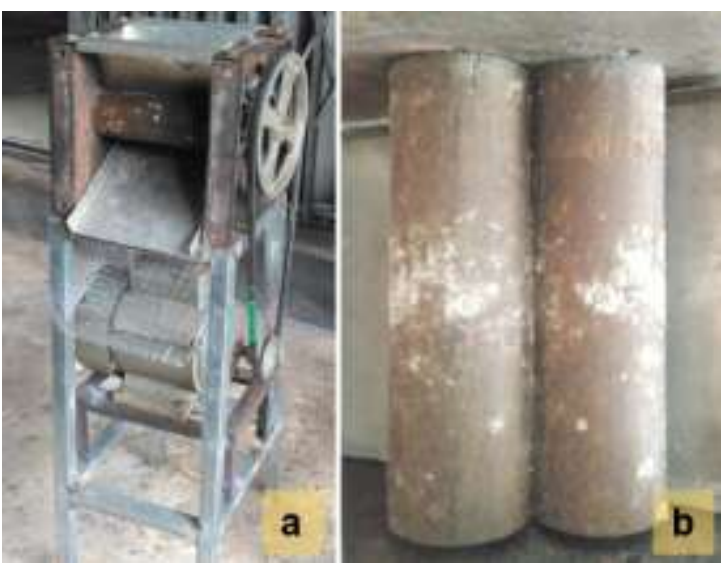

Gambar 4. (a) Prototipe mesin pemipih beras hasil rancang bangun, (b) Posisi rol pemipih pada mesin pemipih

Tabel 1. Spesifikasi mesin pemipih emping beras

\begin{tabular}{ccc}
\hline No & Komponen & Spesifikasi \\
\hline 1 & Dimensi (PxLxT) & $42 \mathrm{~cm} \mathrm{x} 30 \mathrm{~cm} \mathrm{x} 96 \mathrm{~cm}$ \\
\hline 2 & Bobot mesin & $18 \mathrm{~kg}$ \\
\hline 3 & Sistem transmisi & Puli dan sabuk-V \\
\hline 4 & Sistem penggerak & Motor listrik $1 / 2 \mathrm{HP}$ \\
\hline 5 & Mekanisme pemipih & Rol pemipih \\
\hline 6 & Bahan rangka & Baja karbon L 30x30 mm \\
\hline 7 & Kecepatan putar & $360 \mathrm{rpm}$ \\
\hline
\end{tabular}

\section{Hasil pengujian}

Mesin pemipih emping beras merupakan teknik pengembangan sistem pembuatan emping beras secara tradisional. Penggunaan mesin pemipih emping beras bertujuan untuk menggantikan peran tenaga manusia, meningkatkan kualitas dan kapasitas pemipihan emping beras, serta proses pembuatan emping beras dapat dilakukan lebih praktis.

Hasil pengukuran ketebatan emping beras yang dibuat secara tradisional menggunakan jangka sorang diperoleh ratarata tebal $0.98 \mathrm{~mm}$, sedangkan hasil pengukuran tebal beras muda yang digunakan untuk membuat emping adalah $2.05 \mathrm{~mm}$. Pengujian pada mesin pemipih emping beras dilakukan pada kecepatan putar rol pemipih $360 \mathrm{rpm}$. 
Mesin yang digunakan dalam pengujian merupakan mesin pemipih emping beras hasil rancang bangun menggunakan rol pemipih yang terbuat dari kayu. Pengujian pada mesin pemipih emping beras bertujuan mengetahui hubungan lebar celah dan jumlah pemipihan terhadap hasil pemipih emping beras.

\section{Uji kinerja terhadap tebal emping}

Hasil pengujian menunjukkan bahwa lebar celah berbanding lurus dengan ketebalan emping beras yang dihasilkan, semakin lebar celah pemipihan menghasilkan emping yang lebih tebal. Berdasarkan data awal hasil pengukuran, rata-rata tebal beras sebelum dipipih adalah $2.05 \mathrm{~mm}$ sedangkan rata-rata tebal emping yang dibuat secara tradisional dengan cara ditumbuk adalah $0.98 \mathrm{~mm}$. Hasil tersebut mendekati nilai pemipihan menggunakan mesin pada lebar celah $0.8 \mathrm{~mm}$ dengan $2 \mathrm{kali}$ pemipihan yaitu menghasilkan tebal emping $0.96 \mathrm{~mm}$. Ketebalan rata-rata emping yang dihasilkan dari pengujian menggunakan lebar celah pemipihan $0.4 \mathrm{~mm}, 0.6 \mathrm{~mm}, 0.8$ $\mathrm{mm}$ dan $1.0 \mathrm{~mm}$ masing-masing adalah 0.69 $\mathrm{mm}, 0.82 \mathrm{~mm}, 0.98 \mathrm{~mm}$ dan $1.12 \mathrm{~mm}$.

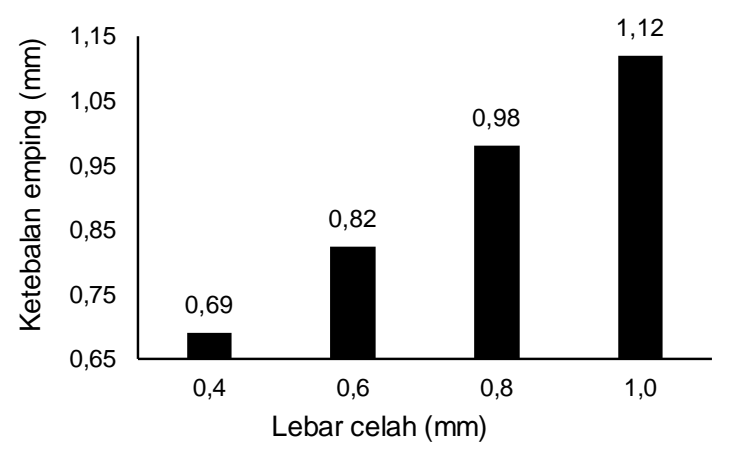

Gambar 5. Hubungan antara lebar celah pemipihan dan rata-rata ketebalan emping

Jumlah pemipihan pada mesin pemipih emping beras dapat mengurangi rata-rata ketebalan emping yang dipipih. Pemipihan pertama dan kedua sangat berpengaruh terhadap perubahan ketebalan emping, sedangkan pemipihan ketiga berpengaruh tetapi tidak signifikan hasilnya terhadap perubahan ketebalan emping yang dipipih menggunakan mesin. Pemipihan pertama mampu menurunkan ketebalan beras dari $2.05 \mathrm{~mm}$ menjadi $0.94 \mathrm{~mm}$ atau terjadi penurunan ketebalan sebesar $54.15 \%$. Pemipihan kedua dan ketiga dapat menurunkan ketebalan emping masingmasing sebesar $56.59 \%$ dan $57.07 \%$.

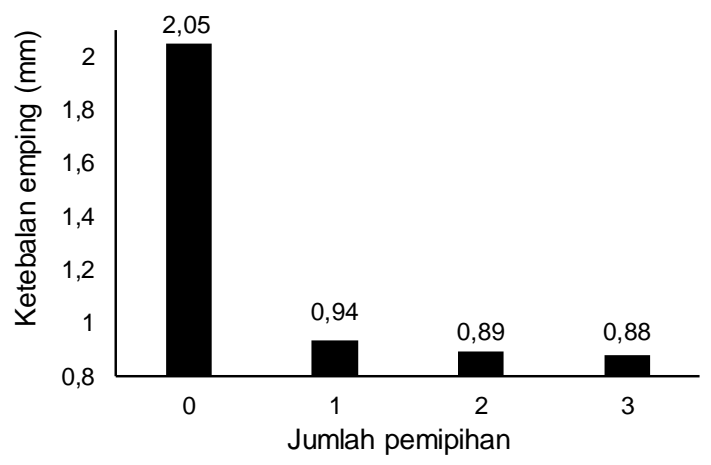

Gambar 6. Hubungan antara jumlah pemipihan dan rata-rata ketebalan emping

\section{Uji kinerja terhadap kerusakan emping}

Hasil pengujian menunjukkan semakin sempit celah dan semakin banyak jumlah pemipihan dapat meningkatkan persentase kerusakan emping beras. Pengujian pada lebar celah $0.4 \mathrm{~mm}$ dan 0.6 $\mathrm{mm}$ menghasilkan sebagian besar emping yang dipipih rusak. Persentase kerusakan tertinggi dalam pengujian diperoleh pada lebar celah pemipihan $0.4 \mathrm{~mm}$ pada pemipihan ketiga dengan persentase kerusakan $81.19 \%$, sedangkan persentase kerusakan terendah diperoleh pada perlakuan lebar celah pemipihan $1.0 \mathrm{~mm}$ pada pemipihan pertama dengan persentase kerusakan $29.52 \%$.

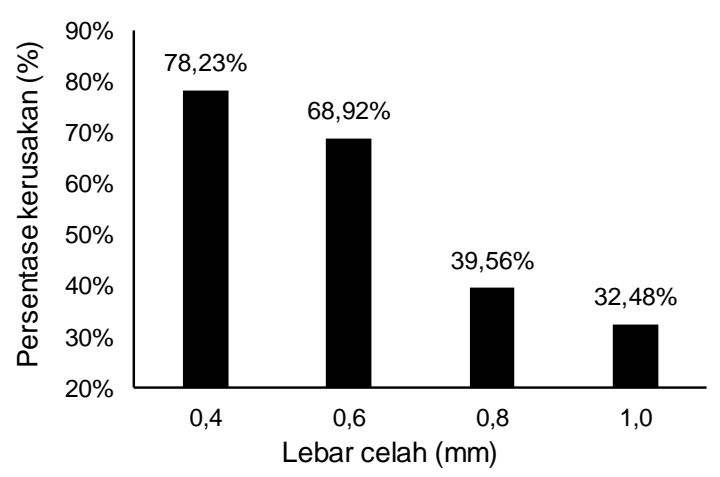

Gambar 7. Hubungan lebar celah terhadap rata-rata persentase kerusakan

Jumlah pemipihan pada proses pembuatan emping beras menggunakan 
mesin berbanding lurus dengan persentase kerusakan emping yang dipipih. Kerusakan terbesar emping dalam pengujian diperoleh pada pemipihan ketiga dengan rata-rata persentase kerusakan $58.06 \%$.

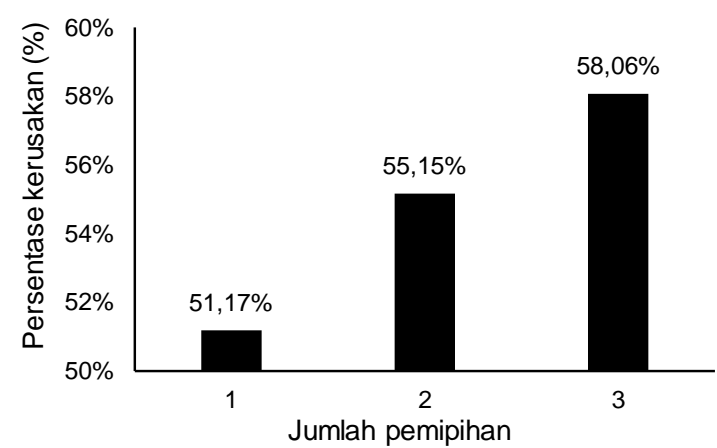

Gambar 8. Hubungan jumlah pemipihan terhadap rata-rata persentase kerusakan

Ketebalan emping beras yang dipipih menggunakan mesin mendekati ketebalan emping yang dibuat secara tradisional pada perlakuan lebar celah pemipih $0.8 \mathrm{~mm}$ dengan 2 kali pemipihan pada kecepatan putar rol pemipih $360 \mathrm{rpm}$. Pada perlakuan tersebut diperoleh persentase kerusakan emping sebesar $38.52 \%$. Persentase kerusakan yang diperoleh masih cukup tinggi, sehingga perlu dilakukan analisis lebih lanjut terhadap celah pemipihan untuk menurunkan tingkat kerusakan emping beras. Analisis lain dapat dilakukan terhadap kecepatan putar rol pemipih untuk mengurangi tingkat kerusakan emping beras.

Faktor lain yang dapat mempengaruhi hasil pemipihan emping beras adalah tingkat kematangan padi dan penyangraian. Penggunaan padi yang terlalu matang untuk membuat emping beras menyebabkan tingkat kerusakan emping semakin tinggi karena struktur padi yang telah matang menjadi lebih keras sehingga mudah hancur saat dipipih. Lama penyangraian juga mempengaruhi kualitas emping beras yang dihasilkan. Penyangraian berperan untuk memanaskan padi yang akan dibuat emping dengan tujuan padi menjadi lebih liat dan tidak mudah hancur saat dipipih. Penyangraian yang terlalu singkat menyebabkan padi menjadi kurang liat sehingga mudah hancur saat dipipih, sedangkan jika disangrai terlalu lama menyebabkan padi gosong dan mengembang sehingga padi juga mudah hancur dan kualitas emping yang dihasilkan menjadi kurang baik.

\section{Kesimpulan}

Konstruksi prototipe mesin pemipih emping beras hasil rancang bangun menghasilkan dimensi (PxLxT) $420 \mathrm{~mm} \mathrm{x}$ $300 \mathrm{~mm} \times 960 \mathrm{~mm}$, bobot mesin $18 \mathrm{~kg}$, sistem transmisi puli dan sabuk-V, sistem penggerak motor listrik 1/2 HP, mekanisme pemipih menggunakan rol terbuat dari balok kayu, kecepatan putar rol pemipih $360 \mathrm{rpm}$.

Hasil pengujian menunjukkan bahwa ukuran lebar celah berbanding lurus dengan ketebalan emping beras yang dihasilkan. Pemipihan pertama dan kedua sangat berpengaruh terhadap perubahan ketebalan emping, sedangkan pemipihan ketiga berpengaruh tetapi tidak signifikan hasilnya terhadap perubahan ketebalan emping.

Pengujian pada lebar celah $0.4 \mathrm{~mm}$ dan $0.6 \mathrm{~mm}$ menghasilkan lebih dari $65 \%$ emping beras yang dipipih rusak. Jumlah pemipihan pada proses pembuatan emping beras menggunakan mesin berbanding lurus dengan persentase kerusakan emping yang dipipih.

Ketebalan emping beras yang dibuat secara tradisional yaitu $0.98 \mathrm{~mm}$ dapat didekati dengan pemipihan menggunakan mesin pada lebar celah $0.8 \mathrm{~mm}$ dengan $2 \mathrm{kali}$ pemipihan menghasilkan tebal emping 0.96 $\mathrm{mm}$ dengan persentase kerusakan $38.52 \%$.

\section{Referensi}

[1]. Rizki A, Yudistira. Rancang Bangun Mesin Pemipih Emping Jagung. J Appl Agric Sci Technol. 2017;1(1):17.

[2]. Yuliana PE, Tambunan STB, Rahayu S. Pembuatan Mesin Emping Melinjo Sistem Roll Bermotor Listrik untuk Usaha Kecil dan Menengah. 2011;

[3]. Setiawan W. Pembuatan Mesin Pemipih Emping Melinjo Kapasitas 50 kg/jam. ik Mesin, Fakultas Teknik, 
Universitas Muaran Kudus; 2012.

[4]. Fiki AR, Mustaqimah M, Nurba D. Perancangan Alat Pemipih Semi Mekanis untuk Biji Melinjo. J Ilm Mhs Pertan Unsyiah. 2017;2(4):53743.

[5]. Sukotjo S. Teknologi Pengolahan Produk Serealia dan Umbi-Umbian, Modul 8. Jakarta: Universitas Terbuka, Departemen Pendidikan Nasional; 2007.

[6]. Champagne ET, Wood DF, Juliano BO, Bechtel DB. Chapter 4: the Rice Grain and Its Gross Composition. RICE: Chemistry and Technology. 2004. 77-107 p.

[7]. Yoshoda S. Fundamentals of Rice Crop Science. International Rice Research Institute. Los Banos, Laguna: International Rice Research Institute; 1981.

[8]. BPS Kabupaten Sambas. Kabupaten Sambas dalam Angka 2018. Sambas: BPS Kabupaten Sambas; 2018.

[9]. Budiyanto, E., Yuono, L. D., \& Farindra, A. (2019). Upaya Peningkatan Kualitas dan Kapasitas Produksi Mesin Pengupas Kulit Kopi Kering. Turbo: Jurnal Program Studi Teknik Mesin, 8(1).

[10]. Setyono ND. Perancangan Mesin Emping Jagung dengan Sistem Roll Pengatur. Universitas Sebelas Maret; 2009.

[11]. Suhendra. Rancang Bangun dan Pengujian Mesin Pengupas Lada (Pipper Nigrum L.) Tipe Silinder Putaran Vertikal. Tesis, Universitas Gadjah Mada, Yogyakarta; 2010. 